\title{
Molecular detection of $\beta$-lactamase and integron genes in clinical strains of Klebsiella pneumoniae by multiplex polymerase chain reaction
}

\author{
Mansour Sedighi[ ${ }^{[1]}$, Masoumeh Halajzadeh ${ }^{[1]}$, Rashid Ramazanzadeh ${ }^{[2],[3]}$, \\ Noor Amirmozafari ${ }^{[1]}$, Mohsen Heidary ${ }^{[1]}$ and Serve Pirouzi ${ }^{[4]}$
}

\begin{abstract}
[1]. Department of Microbiology, School of Medicine, Iran University of Medical Sciences, Tehran, Islamic Republic of Iran. [2]. Cellular \& Molecular Research Center, Kurdistan University of Medical Sciences, Sanandaj, Islamic Republic of Iran. [3]. Department of Microbiology, Faculty of Medicine, Kurdistan University of Medical Sciences, Sanandaj, Islamic Republic of Iran. [4]. School of Hejab, Baneh management, Department of Kurdistan Education and Training, Department of Iran Education and Training, Baneh, Islamic Republic of Iran.
\end{abstract}

\begin{abstract}
Introduction: Infections caused by $\beta$-lactamase-producing gram-negative bacteria, such as Klebsiella pneumoniae, are increasing globally with high morbidity and mortality. The aim of the current study was to determine antimicrobial susceptibility patterns and the prevalence of antibiotic resistance genes ( $\beta$-lactamase and integron genes) using multiplex PCR. Methods: One-hundred K. pneumoniae isolates were collected from different clinical samples. Antibiotic susceptibility testing was performed with thirteen different antibiotics. Multiplex-PCR was used to detect $\beta$-lactamase (bla $a_{\mathrm{TEM}}$, bla $a_{\mathrm{CTX}-\mathrm{M}}$, $b a_{\mathrm{SHY}}, b l a_{\mathrm{VEB}}, b l a_{\mathrm{PER}}, b l a_{\mathrm{GES}}, b l a_{\mathrm{VIM}}$, $b_{l a} a_{\mathrm{IMP}} b l a_{\mathrm{OXA}}$, and $\left.b l a_{\mathrm{KPC}}\right)$ and integron genes (int I, int II, and int III). Results: The highest and lowest rate of resistance was exhibited against amikacin (93\%) and imipenem (8\%), respectively. The frequency of $\beta$-lactamase-positive K. pneumoniae was

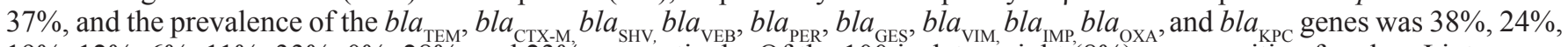
$19 \%, 12 \%, 6 \%, 11 \%, 33 \%, 0 \%, 28 \%$, and $23 \%$, respectively. Of the 100 isolates, eight ( $8 \%$ ) were positive for class I integrons; however, class II and III integrons were not detected in any of the strains. Conclusions: These results indicate co-carriage of a number of $\beta$-lactamase genes and antibiotic resistance integrons on the same plasmids harboring multi-drug resistance genes. It seems that these properties help to decrease treatment complications due to resistant bacterial infections by rapid detection, infection-control programs and prevention of transmission of drug resistance.
\end{abstract}

Keywords: K. pneumoniae. $\beta$-lactamase. Integrons. Drug resistance. Multiplex PCR.

\section{INTRODUCTION}

Klebsiella pneumoniae is an important causative agent of both hospital-acquired and community-acquired infections such as pneumonia, urinary tract infections, meningitis, and septicemia ${ }^{1}$. Multi-drug resistant (MDR) strains can be quite problematic, especially for elderly or immunocompromised patients and infants with an immature physiology ${ }^{2}$. Release of $\beta$-lactamases is a significant resistance mechanism against antimicrobial agents ${ }^{3}$. $\beta$-lactamase-producing $K$. pneumonia can degrade a wide range of $\beta$-lactam antibiotics such as penicillins, carbapenems, cephalosporins, and cephamycins ${ }^{2,4}$. These enzymes can be divided into four classes (A, B, C, and D) based on the Ambler classification. The temoneira (TEM), cefotaximase (CTX-M), sulfhydryl variable (SHV), Vietnam

Corresponding author: Prof. Noor Amirmozafari.

e-mail: amirmozafari@yahoo.com

Received 4 February 2017

Accepted 24 April 2017 extended-spectrum $\beta$-lactamase (VEB), Pseudomonas extendedresistant (PER), and Guiana extended-spectrum (GES) enzymes belong to class A; the Verona integron-encoded metallo$\beta$-lactamase (VIM), imipenem (IMP), and $K$. pneumoniae carbapenemase (KPC) enzymes belong to class B; and oxacillin hydrolyzing enzyme (OXA) is classified as class D according to the Ambler classification ${ }^{5-7}$. Researchers have reported that the incidence of $\beta$-lactamase-producing $K$. pneumonia ranges from 6 to $88 \%$ at different health care locations ${ }^{8} . B l a_{\mathrm{SHV}}$ $\beta$-lactamases are related to high level ceftazidime resistance, but not to cefazolin or cefotaxime resistance, while $b l a_{\text {СTX-M }}$ $\beta$-lactamases are more effective against cefotaxime. In contrast, TEM $\beta$-lactamases confer resistance against oxyimino- $\beta$ lactams groups such as ceftazidime, cefotaxime, and aztreonam. In addition to $\beta$-lactamase encoding plasmids, transportable genetic elements such as integrons can also contribute to the evolution and distribution of MDR genes ( $b l a_{T E M}, b l a_{C T X-M}$, $b l a_{S H V}, b l a_{\mathrm{VEB}}, b l a_{\mathrm{PER}}, b l a_{\mathrm{GES}}, b l a_{\mathrm{VIM}}, b l a_{\mathrm{IMP}}, b l a_{\mathrm{OXA}}$, and $\left.b l a_{\mathrm{KPC}}\right)$ in $K$. pneumoniae by vertical or horizontal transmission ${ }^{9,10}$. Five classes of integrons have been proposed based on the amino acid sequences of Int I proteins. Three classes of antibiotic 
resistance integrons (ARIs; I, II, and III), identified based on particular integrase genes ${ }^{11}$, are usually associated with MDR phenotypes. The transportable class I integron is related to transposon Tn21 and is commonly observed in $\beta$-lactamaseproducing clinical isolates of $K$. pneumonia ${ }^{12}$. Class II integrons are detected less frequently in $b l a_{\mathrm{KPC}}$-producing bacteria, such as $K$. pneumoniae and Escherichia coli, and class III integrons are detected quite infrequently in $\beta$-lactamase-producing $K$. pneumoniae ${ }^{13}$. Previous reports have demonstrated the production of various $\beta$-lactamases, such as bla-ESBL, and resistance to several antibiotics groups via ARI gene carriage in clinical isolates of $K$. pneumonia ${ }^{14}$. Unfortunately, the incidence of $\beta$-lactamase-producing $K$. pneumoniae is on the rise $^{15}$. The detection of different $\beta$-lactamase genes in resistant bacteria and characterization of their antimicrobial susceptibility profiles could provide important data regarding high risk factors and infection epidemiology ${ }^{16-18}$. To date, only a few studies have investigated the types of $\beta$-lactamase-producing Enterobacteriaceae and strains possessing integrons present in Iranian hospitals ${ }^{19,20}$. Thus, the aim of the present study was to determine the prevalence of $b l a_{\mathrm{TEM}}, b l a_{\mathrm{CTX}-\mathrm{M},} b l a_{\mathrm{SHV}}, b l a_{\mathrm{VEB}}$, $b l a_{\mathrm{PER}}, b l a_{\mathrm{GES}}, b l a_{\mathrm{VIM}}, b l a_{\mathrm{IMP}}, b l a_{\mathrm{OXA}}$, and bla $_{\mathrm{KPC}}$, as well as int genes (I, II and III) in clinical K. pneumonia strains isolated from two large urban university general hospitals in Tehran, Iran using multiplex-polymerase chain reaction (M-PCR).

\section{METHODS}

This cross-sectional study was conducted from April 2014 to March 2015, at two teaching hospitals in Tehran, Iran. One hundred non-repetitive $K$. pneumonia isolates were obtained from different clinical specimens including blood, skin lesions, broncho-alveolar lavage (BAL), urine, sputum, cerebrospinal fluid (CSF), pus, pleural effusion, ascites, and catheter specimens. Each sample was cultured on MacConkey agar (Merck, Darmstadt, Germany) and incubated at $37^{\circ} \mathrm{C}$ for 24h. Resulting colonies were identified as K. pneumonia using standard biochemical and microbiological tests, including urease, oxidase, motility, citrate utilization, Triple sugar iron agar (TSI), Methyl Red-Voges Proskauer (MR-VP), and Sulfide Indole Motility (SIM), and were further confirmed with the API 20E system (Analytab, Inc., New York).

Antibiotic susceptibilities were determined using the disc diffusion method on Mueller-Hinton Agar (Merck Co., Germany) plates in accordance with the Clinical and Laboratory Standards Institute (CLSI) guidelines for the following antibiotics (Mast, Merseyside, UK): amoxicillin/clavulanate (AUG; 20/10 $\mu \mathrm{g}$ ), ciprofloxacin (CIP; $5 \mu \mathrm{g}$ ), amikacin (AK; $30 \mu \mathrm{g}$ ), trimethoprim-sulfamethoxazole (TS; $2.5 \mu \mathrm{g}$ ),

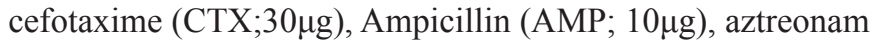

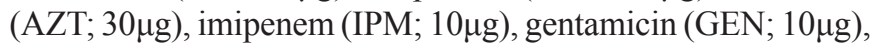

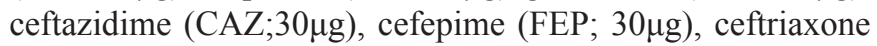

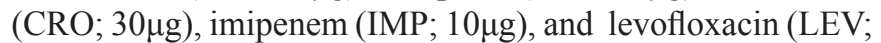
$5 \mu \mathrm{g})$. Briefly, a bacterial suspension was obtained from fresh cultures. The turbidity of each bacterial suspension was adjusted to a value equivalent to the no. $0.5 \mathrm{McF}$ arland turbidity standard and then cultured on Mueller-Hinton agar (Oxoid, UK). The zone of inhibition diameter was measured following incubation at $37^{\circ} \mathrm{C}$ for $18-24$ hours; the results were reported as susceptible, intermediate, and resistant. K. pneumoniae ATCC1029 was used as the quality control ${ }^{14}$.

Multiplex-PCRs were performed to detect $\beta$-lactamase genes

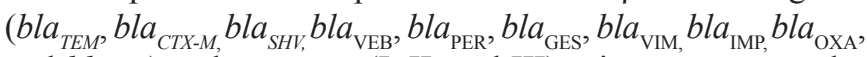
and $\left.b l a_{\mathrm{KPC}}\right)$ and int genes (I, II, and III) using a master cycler gradient (Eppendorf Co., Germany). Genomic deoxyribonucleic acid (DNA) was extracted from $K$. pneumoniae colonies grown overnight on blood agar (Merck Co., Germany) plates using the boiling method ${ }^{14}$. Briefly, a loopful of bacteria from a colony was suspended in $700 \mu \mathrm{l}$ sterile distilled water, boiled for $10 \mathrm{~min}$, centrifuged at $7,000 \times g$ for $4 \mathrm{~min}$ at $4^{\circ} \mathrm{C}$, cooled on ice for $10 \mathrm{~min}$, and then centrifuged for $3 \mathrm{~min}$ at $8,000 \times g$. The concentration and quality of the extracted cellular DNA were assessed using a Nanodrop spectrophotometer (ND-1,000; Thermo Scientific; Wilmington, DE, USA). The $\beta$-lactamase and integron genes were amplified by M-PCR using specific primers detailed in Table 1. M-PCR was carried using $1.5 \mu$ l of extracted genomic DNA in a $25 \mu 1$ PCR reaction mixture consisting of $2.5 \mu 110 \times$ PCR buffer, $1.5 \mu 1 \mathrm{MgCl}_{2}(50 \mathrm{mM}), 0.5 \mu 1 \mathrm{dNTPs}(10 \mathrm{mM}), 1.5 \mu \mathrm{l}$ of each primer, $0.5 \mu \mathrm{l}$ of Taq DNA polymerase $(5 \mathrm{U} / \mu \mathrm{l}$; Amplicon Co., Denmark), and $15.5 \mu 1$ sterile distilled water. M-PCR was performed under the following conditions: denaturation at $94^{\circ} \mathrm{C}$ for $1 \mathrm{~min} ; 35$ cycles of denaturation at $94^{\circ} \mathrm{C}$ for $30 \mathrm{~s}$, annealing at $59^{\circ} \mathrm{C}$ for $30 \mathrm{~s}$, and extension at $72^{\circ} \mathrm{C}$ for $1 \mathrm{~min}$; and a final extension at $72^{\circ} \mathrm{C}$ for $6 \mathrm{~min}$. For amplification of the int genes (I, II, and III), the reaction mixture was amplified using a thermal gradient cycler (Eppendorf Co., Germany) with the following PCR protocol: one cycle of 5 min at $95^{\circ} \mathrm{C} ; 30$ cycles of $1 \mathrm{~min}$ at $95^{\circ} \mathrm{C}, 1 \mathrm{~min}$ at $65^{\circ} \mathrm{C}$, and $1 \mathrm{~min}$ at $72^{\circ} \mathrm{C}$; and one cycle of $10 \mathrm{~min}$ at $72^{\circ} \mathrm{C}^{14}$.

\section{RESULTS}

One-hundred $K$. pneumoniae isolates were obtained from $374(26.7 \%)$ different clinical specimens. Specimens included blood $(n=7,7 \%)$, skin lesions $(n=9,9 \%)$, BAL $(n=5,5 \%)$, urine $(n=62,62 \%)$, sputum $(n=6,6 \%), \operatorname{CSF}(n=3,3 \%)$, Pus/ swap $(n=2,2 \%)$, pleural effusion $(n=1,1 \%)$, ascites $(n=2,2 \%)$, and catheter $(n=3,3 \%)$ samples. Distribution analysis of the $K$. pneumoniae strains showed that most $(62 \%)$ isolates were obtained from urine and the lowest (1\%) number was isolated from pleural effusion samples. The mean age of the population studied was $47 \pm 1.5$ years, with a range of 10 to 76 years. The strains were isolated from patients belonging to various age groups: [(10-25 years; 29), (26-40 years; 38), (41-55 years; 43), (56-60 years; 11), and (60-76 years; 7$)]$. Sixty-seven (67\%) patients were male and $33(33 \%)$ were female.

Antibiotic susceptibility tests using the Kirby-Bauer method showed that the level of resistance to amoxicillin/clavulanate, ciprofloxacin, amikacin, trimethoprim-sulfamethoxazole, cefotaxime, ampicillin, aztreonam, imipenem, gentamicin, ceftazidime, cefepime, ceftriaxone, and levofloxacin was $37 \%$, $37 \%, 93 \%, 84 \%, 52 \%, 87 \%, 59 \%, 8 \%, 24 \%, 67 \%, 52 \%, 43 \%$, and $26 \%$, respectively (Table 2). The antibiotic susceptibility profiles of non- $\beta$-lactamase-producing and $\beta$-lactamaseproducing K. pneumoniae strains are detailed in Table 3. 
TABLE 1

Nucleotide sequences of the primers used for M-PCR.

\begin{tabular}{|c|c|c|}
\hline Genes & Oligonucleotide sequence $\left(5^{\prime} \rightarrow 3^{\prime}\right)$ & Size of amplicon (bp) \\
\hline bla-SHV & $\begin{array}{l}\text { F: 5'-ATGCGTTATATTCGCCTGTG-3' } \\
\text { R: 5'-TGCTTTGTTATTCGGGCCAA-3' }\end{array}$ & 747 \\
\hline bla-TEM-1 & $\begin{array}{l}\text { F: 5'-TCGCCGCATACACTATTCTCAGAATGA-3' } \\
\text { R: 5'-ACGCTCACCGGCTCCAGATTTAT-3' }\end{array}$ & 445 \\
\hline bla-CTX-M & $\begin{array}{l}\text { F: 5'-ATGTGCAGCACCAGTAAAGTGATGGC-3' } \\
\text { R: 5'-TGGGTAAAGTAAGTGACCAGAATCAGCGG-3' }\end{array}$ & 593 \\
\hline bla-PER & $\begin{array}{l}\text { F: 5'-AATTTGGGCTTAGGGCAGAA-3' } \\
\text { R: 5'-ATGAATGTCATTATAAAAGC-3' }\end{array}$ & 925 \\
\hline bla-KPC & $\begin{array}{l}\text { F; 5'-CGTCTAGTTCTGCTGTCTTG -3' } \\
\text { R: 5'-CTTGTCATCCTTGTTAGGCG -3' }\end{array}$ & 538 \\
\hline bla-VEB & $\begin{array}{l}\text { F: 5'-CGACTTCCATTTCCCGATGC-3' } \\
\text { R: 5'-GGACTCTGCAACAAATAC GC-3' }\end{array}$ & 643 \\
\hline bla-VIM & $\begin{array}{l}\text { F: 5'-GATGGTGTTTGGTCGCATA-3' } \\
\text { R: 5'-CGAATGCGCAGCACCAG-3' }\end{array}$ & 390 \\
\hline bla-IMP & $\begin{array}{l}\text { F: 5'-CATGGTTTGGTGGTTCTTGT-3' } \\
\text { R: 5'-ATAATTTGGCGGACTTTGGC-3' }\end{array}$ & 448 \\
\hline bla-OXA & $\begin{array}{l}\text { F: 5'-AGC CGT TAA AAT TAA GCC C-3' } \\
\text { R: 5'-CTT GAT TGA AGG GTT GGG CG-3' }\end{array}$ & 919 \\
\hline intI & $\begin{array}{l}\text { F: 5'-GCCTTGCTGTTCTTCTACGG-3' } \\
\text { R: 5'-GATGCCTGCTTGTTCTACGG-3' }\end{array}$ & 558 \\
\hline intII & $\begin{array}{l}\text { F: 5'-CACGGATATGCGACAAAAAGGT-3' } \\
\text { R: 5'-GTAGCAAACGAGTGACGAAATG-3' }\end{array}$ & 789 \\
\hline
\end{tabular}

M-PCR: multiplex polymerase chain reaction; bla-TEM-1: temoniera $\beta$-lactamase-1; bla-CTX-M: cefotaximase; $\boldsymbol{b l a - S H V}$ : sulphydril variable $\beta$-lactamase; bla-PER: Pseudomonas extended resistance; bla-KPC: Klebsiella pneumoniae carbapenemase; bla-VEB: Vietnamese extended spectrum beta-lactamase; bla-GES: Guiana Extended Spectrum $\beta$-Lactamases; bla-VIM: Verona imipenemase; bla-IMP: imipenemase; bla-OXA: oxacilinases; Int I: class I integrons; Int II: class II integrons; Int III: class III integrons.

TABLE 2

Antibiotic resistance patterns in Klebsiella pneumoniae isolates.

\begin{tabular}{|c|c|c|c|c|c|c|}
\hline Antibiotic & \multicolumn{2}{|c|}{ Resistant } & \multicolumn{2}{|c|}{ Intermediate } & \multicolumn{2}{|c|}{ Susceptible } \\
\hline Amoxicillin/clavulanate (Aug) & 37 & 37.0 & 0 & 0.0 & 63 & 63.0 \\
\hline Amikacin (AK) & 93 & 93.0 & 3 & 3.0 & 4 & 4.0 \\
\hline Trimethoprim-sulfamethoxazole (TS) & 84 & 84.0 & 4 & 4.0 & 12 & 12.0 \\
\hline Ampicillin (AMP) & 87 & 87.0 & 2 & 2.0 & 11 & 11.0 \\
\hline Aztreonam(AZT) & 59 & 59.0 & 1 & 1.0 & 40 & 40.0 \\
\hline Imipenem (IPM) & 8 & 8.0 & 9 & 9.0 & 83 & 83.0 \\
\hline Gentamicin (GEN) & 24 & 24.0 & 6 & 6.0 & 70 & 70.0 \\
\hline Levofloxacin (LEV) & 26 & 26.0 & 0 & 0.0 & 74 & 74.0 \\
\hline
\end{tabular}


TABLE 3

Antibiotic resistance rates of non- $\beta$-lactamase-producing and $\beta$-lactamase-producing Klebsiella pneumoniae strains.

\begin{tabular}{|c|c|c|}
\hline Antibiotic & $\begin{array}{c}\text { Non- } \beta \text {-lactamase-producing } \\
\text { Klebsiella pneumoniae strains (\%) }\end{array}$ & $\begin{array}{c}\beta \text {-lactamase-producing Klebsiella pneumoniae } \\
\text { strains (\%) }\end{array}$ \\
\hline Amoxicillin/clavulanate (Aug) & 37.0 & 63.0 \\
\hline Amikacin (AK) & 18.0 & 45.0 \\
\hline Trimethoprim-sulfamethoxazole (TS) & 32.0 & 31.0 \\
\hline Ampicillin (AMP) & 35.0 & 28.0 \\
\hline Aztreonam(AZT) & 12.0 & 51.0 \\
\hline Imipenem (IPM) & 6.0 & 57.0 \\
\hline Gentamicin (GEN) & 31.0 & 32.0 \\
\hline Ceftazidime (CAZ) & 33.0 & 30.0 \\
\hline Levofloxacin (LEV) & 7.0 & 56.0 \\
\hline
\end{tabular}

The $\beta$-lactamase gene amplification test (M-PCR) simultaneously amplified and identified the existence of the target genes and showed that the prevalence of the $b l a_{T E M}$, bla $a_{C T X-M}$, bla $a_{S H V}$ bla $a_{\mathrm{VEB}}$, bla $a_{\mathrm{PER}}, b l a_{\mathrm{GES}}$, bla $_{\mathrm{VIM}}$, bla $_{\mathrm{IMP},}$ bla $a_{\mathrm{OXA}}$, and bla $a_{\mathrm{KPC}}$ genes was $38 \%, 24 \%, 19 \%, 12 \%, 6 \%, 11 \%, 33 \%, 0 \%, 28 \%$, and $23 \%$, respectively (Figure 1). Molecular distribution analysis of the integron genes showed that only $11(8.6 \%)$ of the 100 isolates contained class I integrons; however, class II and class III integrons were not detected in any of the isolates (Figure 2).

\section{DISCUSSION}

$\beta$-lactamase-producing $K$. pneumoniae was first identified in $1983^{21}$. Most infections caused by K. pneumoniae are due to multi-drug resistant strains such as $\beta$-lactamase producing isolates $^{22}$. Recent studies have shown that the incidence of $\beta$-lactamase-producing $K$. pneumoniae is increasing in several countries such as $\operatorname{Iran}^{22,23}$, India ${ }^{24,25}$, and Italy ${ }^{26}$. Resistance to various antibiotics is related to the existence of transmissible plasmids and integrons, which can be integrated into plasmids or the chromosome ${ }^{27}$. These transmissible elements often contain resistance factors that can be transferred to other microorganisms. In this study, we examined the susceptibility of 100 clinical $K$. pneumonia strains against thirteen antibiotics; high resistance was observed for AK (93\%), TS (84\%), AMP (87\%), AZT (59\%), GEN (67\%), and FEP (52\%). Amiri et al. ${ }^{28}$ reported that the resistance to ampicillin, ceftazidime, ceftriaxone, aztreonam, and cefotaxime was $92 \%, 67 \%, 65 \%, 64 \%$, and $59 \%$, respectively in $K$. pneumoniae isolates ${ }^{28}$, values similar to the rates reported in this study. Our results indicate that only eight $\beta$-lactamase-producing isolates were resistant to imipenem using the disk diffusion method. This high (83\%) susceptibility to imipenem is in agreement with the reports of Mansury et al. ${ }^{29}$, Ahmad et al. ${ }^{30}$, Amiri et al. ${ }^{28}$, and Edelstein et al. ${ }^{31}$. Only three $K$. pneumoniae isolates were resistant to all antibiotics tested.
Multi-drug resistant (MDR) strains are defined as strains resistant to three classes of antimicrobial agents ${ }^{32}$; therefore, $31 \%$ of our isolates can be classified as MDR. This finding contrasts those reported by Mansury et al. ${ }^{29}$. A total of $52 \%$ and $67 \%$ of our isolates were resistant to the third generation cephalosporins ceftazidime and cefotaxime, respectively,

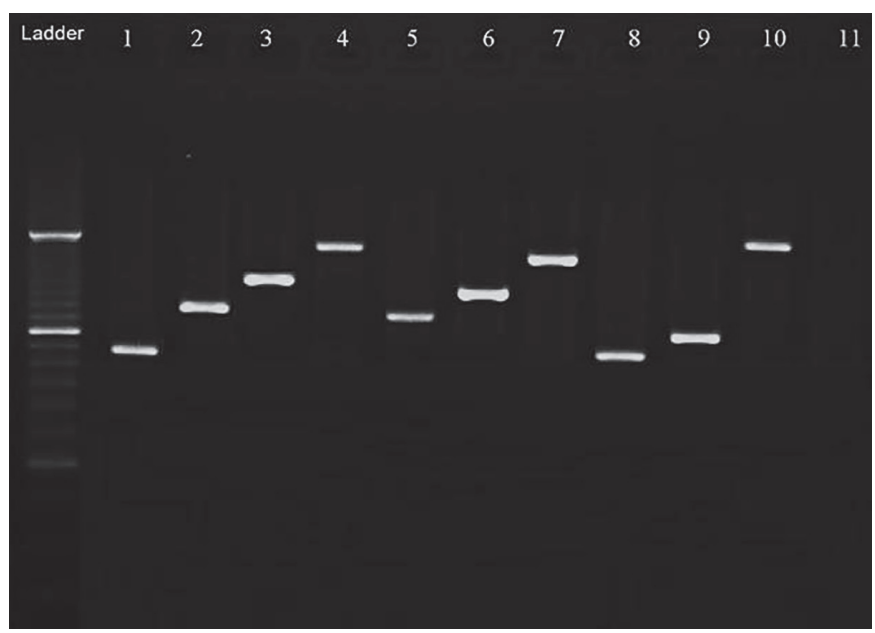

FIGURE 1 - M-PCR amplification of $\beta$-lactamase genes in selected Klebsiella pneumoniae isolates. Lane 1: bla-TEM-1 (447bp), Lane 2: blaCTX-M (593bp), Lane 3: bla-SHV gene (747bp), Lane 4: bla-PER (925bp), Lane 5: bla-KPC (538bp), Lane 6: bla-VEB (643bp), Lane 7: bla-GES (860bp), Lane 8: bla-VIM (390bp), Lane 9: bla-IMP (448bp), Lane 10: bla-OXA (919bp), Lane 11: negative control; Escherichia coli ATCC 25922, Ladder: 50bp DNA size ladder. M-PCR: multiplex polymerase chain reaction; $\boldsymbol{b l a - T E M - 1 :}$ temoniera $\beta$-lactamase-1; bla-CTX-M: Cefotaximase; bla-SHV: sulphydril variable $\beta$-lactamase; bla-PER: Pseudomonas extended resistance; $\boldsymbol{b l a}-\boldsymbol{K} \boldsymbol{P C}$ : Klebsiella pneumoniae carbapenemase; bla-VEB: Vietnamese extended spectrum beta-lactamase; bla-GES: Guiana Extended Spectrum $\beta$-Lactamases; bla-VIM: Verona imipenemase; bla-IMP: Imipenemase; bla-OXA: oxacilinases; DNA: deoxyribonucleic acid. 


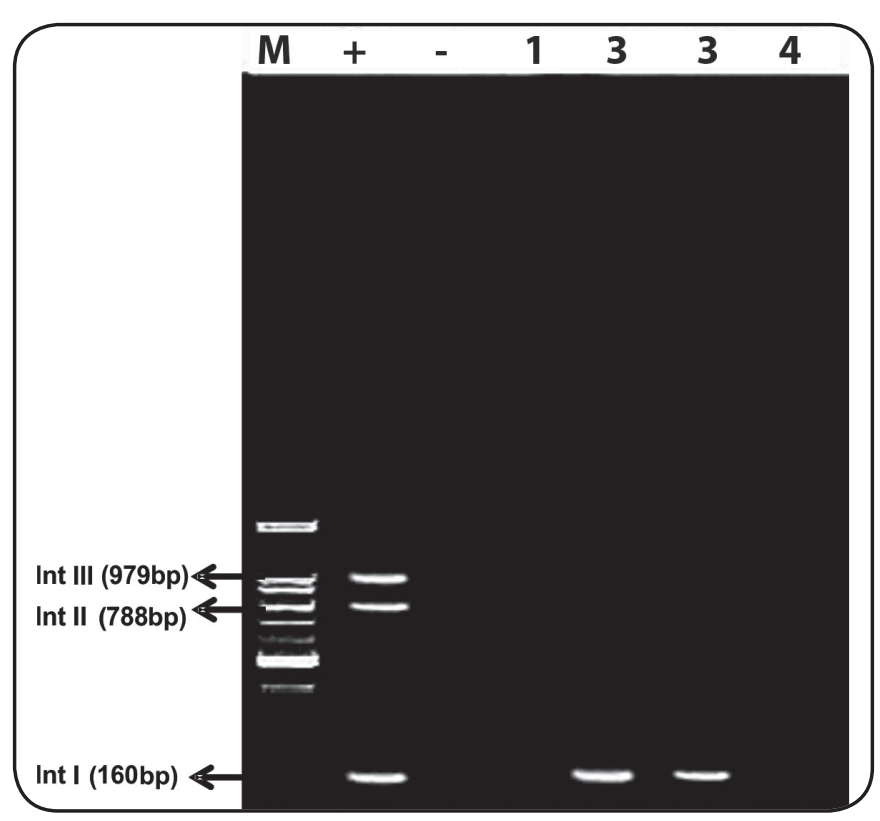

FIGURE 2 - M-PCR amplification of int genes in four selected Klebsiella pneumoniae isolates. M: $100 \mathrm{bp}$ DNA size marker; Lane +: quality control $(K$. pneumoniae ATCC 1029); Lane -: negative control (Escherichia coli ATCC 25922), Lane 1-4: M-PCR gene products. Int I: class I integrons; Int II: class II integrons; Int III: class III integrons; M-PCR: multiplex polymerase chain reaction; DNA: deoxyribonucleic acid.

which is similar to the rates reported by Ullah et al. ${ }^{33}$, Amiri et al. ${ }^{28}$, and Jalalpoor et al. ${ }^{34}$. Of the MDR isolates, 28 strains were $\beta$-lactamase-positive (28\%). These results are in agreement with those of Shukla et al. ${ }^{35}$ and Sarojamma et al. ${ }^{36}$ who reported that $28 \%$ and $32 \%$ of their strains were $\beta$-lactamase producers, respectively ${ }^{35,36}$. The incidence of $\beta$-lactamase-producing Klebsiella spp. has been reported to vary from $42-44 \%$ (in the USA) $)^{37-39}, 4.9 \%$ (in Canada) ${ }^{40}, 20.8 \%$ (in Spain) ${ }^{41}, 28.4 \%$ (in Taiwan) ${ }^{42}, 78.6 \%$ (in Turkey) ${ }^{43}, 20 \%$ (in Algeria) ${ }^{44}$, and $51 \%$ (in China $)^{45}$. In this study, the highest percentage of $\beta$-lactamaseroducing strains was derived from urine samples (14\%).

The aim of this study was to determine the prevalence of several $\beta$-lactamase and integrin genes (I, II, III) in clinical $K$. pneumoniae isolates. The M-PCR results for each resistance gene were as follows: $b l a_{\text {TEM }}$ was detected in $37.8 \%$ (14.37), bla $_{C T X}$ in $24.3 \%$ (9.37), bla ${ }_{S H V}$ in $18.9 \%$ (7.37), bla ${ }_{\mathrm{VEB}}$ in $10.8 \%$ (4.37), bla $a_{\mathrm{PER}}$ in $5.4 \%$ (2.37), bla $a_{\mathrm{GES}}$ in $10.8 \%$ (4.37), bla ${ }_{\mathrm{VIM}}$ in $8.1 \%(3.37), b l a_{\mathrm{IMP}}$ in $0 \%(0.37), b l a_{\mathrm{OXA}}$ in $27 \%(10.37)$, and $b l a_{\mathrm{KPC}}$ in $24.3 \%(9.37)$ of the isolates. Bora et al. ${ }^{46}$ reported that of the three $\beta$-lactamase genotypes, bla $_{T E M}$ in detected most predominately in $\beta$-lactamase-producing $K$. pneumoniae $(77.58 \%)^{46}$. Monstein et al. ${ }^{47}$ detected $b l a_{\mathrm{SHV}}$ in $8.1 \%$ (3.37); $b l a_{\mathrm{SHV}}$ and $b l a_{\mathrm{TEM}}$ in $2.7 \%(1.37)$; and $b l a_{\mathrm{TEM}}, b l a_{\mathrm{SHV}}$, and bla $_{\text {Стх-м }}$ in 8\% (3.37) of their K. pneumonia isolates ${ }^{47}$. Hassan and Abdalhamid. ${ }^{48}$ reported a very high prevalence of $b l a_{C T X-\mathrm{M}}$ $(97.4 \%)$ in comparison to the prevalence of $b l a_{S H V}(23.1 \%)$ in $K$. pneumoniae strains ${ }^{48}$. However, in Europe, East Asia, and Latin America, as well as in the current study, $b l a_{T E M}, b l a_{C T X}$, and $b l a_{S H V}$ appear to be the predominant $\beta$-lactamase genes in clinical $K$. pneumoniae isolates.
Ahmed et al. ${ }^{49}$ reported that the prevalence of $b l a_{\text {PER }}$ was $22.4 \%$; however Nasehi et al. ${ }^{20}$, detected $b l a_{\mathrm{PER}}$ in only $7.5 \%$ of their isolates, which is similar to the results of this study. BorgesCabral et al. ${ }^{50}$, reported that bla $_{\mathrm{KPC}}$ was present in $41.7 \%$ of their isolates; however, Bina et al..$^{51}$ did not observed $b l a_{\mathrm{KPC}}(0 \%)$ in any of their strains and the rate in the present study was $23 \%$. Limbago et al..$^{52}$ observed the $b l a_{\mathrm{IMP}}$ gene in all of their clinical $K$. pneumoniae isolates; however, we did not detect this gene in any of our isolates. Udomsantisuk et al..$^{53}$ reported that the frequency of the $b l a_{\mathrm{VEB}}$ gene was $30 \%$ among $\beta$-lactamase-positive $K$. pneumoniae strains; however, in the current study, the frequncy of $b l a_{\mathrm{VEB}}$ gene was $12 \%$. Iraz et al. ${ }^{54}$ reported that $86 \%$ of the carbapenem-resistant K. pneumoniae strains carried the $b l a_{\mathrm{OXA}}$ gene; however, Charrouf et al..$^{55}$ found that only $6 \%$ of their isolates carried this gene. Our results did not match either of these studies; in our study, the prevalence of this gene was $28 \%$. Psichogiou et al. ${ }^{56}$ found that the frequency of the $b l a_{\text {VIM }}$ gene in clinical $K$. pneumoniae strains was $37.6 \%$, which is consistent with our results (33\%). This reflects a significant increase in the prevalence of $b l a_{T E M}$ and $b l a_{\mathrm{VIM}}$ in Iran. In comparison, the major $\beta$-lactamase gene found in Arab countries appears to be $b l a_{\mathrm{CTX}-\mathrm{M}}{ }^{57-59}$.

In addition to $\beta$-lactamase genes, we also evaluated integron gene prevalence in the $100 \mathrm{~K}$. pneumoniae isolates. Our results indicate that only eight isolates were positive for class I integrons, while class II and class III integrons were not detected in any of the isolates. This finding is comparable to those of Lima et al. ${ }^{60}$ and Ashayeri et al. ${ }^{61}$. Class III integrons have been reported only in very few studies ${ }^{14,62,63}$. MobarakQamsari et al. ${ }^{64}$ identified 22 (44\%) class I integron-carrying K. pneumoniae isolates, but only three $(6 \%)$ of the isolates had class II integrons and none contained class III integrons ${ }^{64}$. These findings suggest that class I integron genes may play a critical role in the distribution of $\beta$-lactamase-encoding genes among clinical $\beta$-lactamase-producing $K$. pneumoniae isolates. The increase in multidrug resistance and the underlying mechanisms require further investigation

In conclusions, our study demonstrates that there is a high level of $b l a_{\mathrm{TEM},} b l a_{\mathrm{VIM}}$, and class I integrons in the $\beta$-lactamaseproducing $K$. pneumoniae strains circulating in hospitals in Tehran, Iran. This trend of MDR profiles associated with the presence of $b l a_{\mathrm{TEM},} b l a_{\mathrm{VIM}}$, and class I integron genes is worrying. The high prevalence rate of these resistance genes highlights the necessity for establishing a national antibiotic susceptibility surveillance network for monitoring infections due to Enterobacteriaceae spp. in Iran. It seems that these properties help to decrease treatment complications and mortality rate due to resistant bacterial infections by rapid detection of $\beta$-lactamases genes, infection-control programs and prevention of transmission of drug resistant-strains. A combination therapy can be useful to prevent resistance during therapy resulting in complete remission of patient and resistant infections control. One of the limitations of the present study was that, other $\beta$-lactamases family genes and also other antibiotic resistance mechanisms were not assessed due to the financial constraints of molecular and gene tests. So, further investigations are needed to obtain more accurate and effective results. 


\section{Acknowledgments}

The authors are greatly thankful to Serwa Pirouzi and Saadat Pirouzi for help with the English language version of this paper. Also, authors would like to thank the director and principal of Iran university of medical sciences for their constant encouragement and support for the current study.

\section{Conflict of interest}

The authors declare that there is no conflict of interest in the present study.

\section{REFERENCES}

1. Tsay R-W, Siu L, Fung C-P, Chang F-Y. Characteristics of bacteremia between community-acquired and nosocomial Klebsiella pneumoniae infection: risk factor for mortality and the impact of capsular serotypes as a herald for community-acquired infection. Arch Intern Med. 2002;162(9):1021-7.

2. Hirsch EB, Tam VH. Detection and treatment options for Klebsiella pneumoniae carbapenemases (KPCs): an emerging cause of multidrug-resistant infection. J Antimicrob Chemother. 2010;65(6):1119-25.

3. Paterson DL, Hujer KM, Hujer AM, Yeiser B, Bonomo MD, Rice LB, et al. Extended-spectrum $\beta$-lactamases in Klebsiella pneumoniae bloodstream isolates from seven countries: dominance and widespread prevalence of SHV-and CTX-M-type $\beta$-lactamases. Antimicrob Agents Chemother. 2003;47(11):3554-60.

4. Machado E, Coque TM, Cantón R, Novais A, Sousa JC, Baquero F, et al. High diversity of extended-spectrum $\beta$-lactamases among clinical isolates of Enterobacteriaceae from Portugal. J Antimicrob Chemother. 2007;60(6):1370-4.

5. Branger C, Zamfir O, Geoffroy S, Laurans G, Arlet G, Thien HV, et al. Genetic background of Escherichia coli and extendedspectrum beta-lactamase type. Emerg Infect Dis. 2005;11(1):54-61.

6. Sedighi M, Salehi-Abargouei A, Oryan G, Faghri J. Epidemiology of VIM-1-imipenem resistant Pseudomonas aeruginosa in Iran: A systematic review and meta-analysis. J Res Med Sci. 2014;19(9):899903.

7. Ramazanzadeh R, Rouhi S, Shakib P. Molecular Detection of Extended-Spectrum Beta-Lactamase in Isolated Bacteria from Blood Cultures. J Med Bacteriol. 2015;4(1-2):27-34.

8. SharMa M, PathaK S, SrivaStava P. Prevalence and antibiogram of Extended Spectrum $\beta$-Lactamase (B-lactamase) producing Gram negative bacilli and further molecular characterization of B-lactamase producing Escherichia coli and Klebsiella spp. J Clin Diagn Res. 2013;7(10):2173-7.

9. Ramazanzadeh R. Prevalence and characterization of extendedspectrum beta-lactamase production in clinical isolates of Klebsiella spp. Afr J Microbiol Res. 2010;4(13):1359-62.

10. Bush K, Jacoby GA. Updated functional classification of $\beta$-lactamases. Antimicrob Agents Chemother. 2010;54(3):969-76.

11. Laroche E, Pawlak B, Berthe T, Skurnik D, Petit F. Occurrence of antibiotic resistance and class 1, 2 and 3 integrons in Escherichia coli isolated from a densely populated estuary (Seine, France). FEMS Microbiol Ecol. 2009;68(1):118-30.

12. Poirel L, Le Thomas I, Naas T, Karim A, Nordmann P. Biochemical sequence analyses of GES-1, a novel class A extended-spectrum $\beta$-lactamase, and the class 1 integron In52 from Klebsiella pneumoniae. Antimicrob Agents Chemother. 2000;44(3):622-32.
13. Correia M, Boavida F, Grosso F, Salgado M, Lito L, Cristino JM, et al. Molecular characterization of a new class 3 integron in Klebsiella pneumoniae. Antimicrob Agents Chemother. 2003;47(9):2838-43.

14. Ashayeri-Panah M, Feizabadi MM, Eftekhar F. Correlation of multidrug resistance, integron and bla $\beta$-lactamase gene carriage with genetic fingerprints of extended-spectrum $\beta$-lactamase producing Klebsiella pneumoniae. Jundishapur J Microbiol. 2014;7(2):1-6.

15. Endimiani A, Hujer AM, Hujer KM, Gatta JA, Schriver AC, Jacobs $\mathrm{MR}$, et al. Evaluation of a commercial microarray system for detection of SHV-, TEM-, CTX-M-, and KPC-type $\beta$-lactamase genes in Gramnegative isolates. J Clin Microbiol. 2010;48(7):2618-22.

16. Tumbarello M, Spanu T, Sanguinetti M, Citton R, Montuori $\mathrm{E}$, Leone $\mathrm{F}$, et al. Bloodstream infections caused by extendedspectrum- $\beta$-lactamase-producing Klebsiella pneumoniae: risk factors, molecular epidemiology, and clinical outcome. Antimicrob Agents Chemother. 2006;50(2):498-504.

17. Sedighi M, Vaez H, Moghoofeie M, Hadifar S, Oryan G, Faghri J. Molecular detection of metallo- $\beta$-lactamase gene blaVIM-1 in imipenem resistant Pseudomonas aeruginosa strains isolated from hospitalized patients in the hospitals of Isfahan. Adv Biomed Res. 2015;4(57):1-5.

18. Ramazanzadeh R. Etiologic agents and extended-spectrum betalactamase production in urinary tract infections in Sanandaj, Iran. East J Med. 2010;15(2):57-62.

19. Feizabadi MM, Delfani S, Raji N, Majnooni A, Aligholi M, Shahcheraghi F, et al. Distribution of bla TEM, bla SHV, bla CTX-M genes among clinical isolates of Klebsiella pneumoniae at Labbafinejad Hospital, Tehran, Iran. Microb Drug Resist. 2010;16(1):49-53.

20. Nasehi L, Shahcheraghi F, Nikbin VS, Nematzadeh S. PER, CTX-M, TEM and SHV Beta-lactamases in clinical isolates of Klebsiella pneumoniae isolated from Tehran, Iran. Iran J Basic Med Sci. 2010;13(3):111-8.

21. Knothe H, Shah PDP, Krcmery V, Antal M, Mitsuhashi S. Transferable resistance to cefotaxime, cefoxitin, cefamandole and cefuroxime in clinical isolates of Klebsiella pneumoniae and Serratia marcescens. Infect. 1983;11(6):315-7.

22. Ramazanzadeh R, Chitsaz M, Bahmani N. Prevalence and antimicrobial susceptibility of extended-spectrum beta-lactamaseproducing bacteria in intensive care units of Sanandaj general hospitals (Kurdistan, Iran). Chemotherapy. 2009;55(4):287-92.

23. Derakhshan S, Peerayeh SN, Fallah F, Bakhshi B, Rahbar M, Ashrafi A. Detection of class 1, 2, and 3 integrons among Klebsiella pneumoniae isolated from children in Tehran hospitals. Arch Pediatr Infect Dis. 2014;2(1):164-8.

24. Hansotia JB, Agarwal V, Pathak A, Saoji A. Extended spectrum betalactamase mediated resistance to third generation cephalosporins in Klebsiella pneumoniae in Nagpur, central India. Indian J Med Res. 1997;105:158-61.

25. Manchanda V, Singh N, Goyal R, Kumar A, Thukral S. Phenotypic characteristics of clinical isolates of Klebsiella pneumoniae \& evaluation of available phenotypic techniques for detection of extended spectrum beta-lactamases. Indian J Med Res. 2005;122(4):330-7.

26. Perilli M, Dell'Amico E, Segatore B, de Massis MR, Bianchi C, Luzzaro F, et al. Molecular characterization of extendedspectrum $\beta$-lactamases produced by nosocomial isolates of Enterobacteriaceae from an Italian nationwide survey. J Clin Microbiol. 2002;40(2):611-4.

27. Ranjbar R, Giammanco GM, Farshad S, Owlia P, Aleo A, Mammina C. Serotypes, antibiotic resistance, and class 1 integrons 
in Salmonella isolates from pediatric cases of enteritis in Tehran, Iran. Foodborne Pathog Dis. 2011;8(4):547-53.

28. Amiri A, Firoozeh F, Moniri R, Zibaei M. Prevalence of CTX-Mtype and PER extended-spectrum $\beta$-lactamases among Klebsiella spp. isolated from clinical specimens in the Teaching Hospital of Kashan, Iran. Iran Red Crescent Med J. 2016;18(3):1-7.

29. Mansury D, Motamedifar M, Sarvari J, Shirazi B, Khaledi A. Antibiotic susceptibility pattern and identification of extended spectrum $\beta$-lactamases (B-lactamase) in clinical isolates of Klebsiella pneumoniae from Shiraz, Iran. Iran J Microbiol. 2016;8(1):55-60.

30. Ahmad S, Al-Juaid NF, Alenzi FQ, Mattar EH, Bakheet OE-S. Prevalence, Antibiotic Susceptibility Pattern and Production of Extended-Spectrum $\beta \beta$-Lactamases Amongst Clinical Isolates of Klebsiella pneumoniae at Armed Forces Hospital in Saudi Arabia. J Coll Physicians Surg Pak. 2009;19(4):264-5.

31. Edelstein M, Pimkin M, Palagin I, Edelstein I, Stratchounski L. Prevalence and molecular epidemiology of CTX-M extendedspectrum $\beta$-lactamase-producing Escherichia coli and Klebsiella pneumoniae in Russian hospitals. Antimicrob Agents Chemother. 2003;47(12):3724-32.

32. Paterson DL. Resistance in gram-negative bacteria: Enterobacteriaceae. Am J Med. 2006;119(6):20-8.

33. Ullah F, Malik SA, Ahmed J. Antimicrobial susceptibility pattern and ESBL prevalence in Klebsiella pneumoniae from urinary tract infections in the North-West of Pakistan. Afr J Microbiol Res. 2009;3(11):676-80.

34. Jalalpoor S. Antibiotic resistant pattern in B-lactamase producer Klebsiella pneumoniae strains isolated of hospitalized and out patients acquired urinary tract infection. Majallahi Danishkadahi Pizishkii Isfahan. 2011;29(142):14-19.

35. Shukla I, Tiwari R, Agrawal M. Prevalence of extended spectrumlactamase producing Klebsiella pneumoniae in a tertiary care hospital. Indian J Med Microbiol. 2004;22(2):87-91.

36. Sarojamma V, Ramakrishna V. Prevalence of ESBL-producing Klebsiella pneumoniae isolates in tertiary care hospital. ISRN Microbiol. 2011;2011:1-5.

37. Saurina G, Quale JM, Manikal VM, Oydna E, Landman D. Antimicrobial resistance in Enterobacteriaceae in Brooklyn, NY: epidemiology and relation to antibiotic usage patterns. J Antimicrob Chemother. 2000;45(6):895-8.

38. Mathai D, Lewis MT, Kugler KC, Pfaller MA, Jones RN, Hospital $\mathrm{CHM}$, et al. Antibacterial activity of 41 antimicrobials tested against over 2773 bacterial isolates from hospitalized patients with pneumonia: I-results from the SENTRY Antimicrobial Surveillance Program (North America, 1998). Diagn Microbiol Infect Dis. 2001;39(2):105-16.

39. Winokur P, Canton R, Casellas J-M, Legakis N. Variations in the prevalence of strains expressing an extended-spectrum $\beta$-lactamase phenotype and characterization of isolates from Europe, the Americas, and the Western Pacific region. Clin Infect Dis. 2001;32(2):94-103.

40. Cordero L, Rau R, Taylor D, Ayers LW. Enteric gram-negative bacilli bloodstream infections: 17 years' experience in a neonatal intensive care unit. Am J Infect Control. 2004;32(4):189-95.

41. Romero EDV, Padilla TP, Hernández AH, Grande RP, Vázquez MF, García IG, et al. Prevalence of clinical isolates of Escherichia coli and Klebsiella spp. producing multiple extended-spectrum $\beta$-lactamases. Diagn Microbiol Infect Dis. 2007;59(4):433-7.

42. Kuo K, Shen Y, Hwang K. Clinical implications and risk factors of extended-spectrum beta-lactamase-producing Klebsiella pneumoniae infection in children: a case-control retrospective study in a medical center in southern Taiwan. J Microbiol Immunol Infect. 2007;40(3):248-54.

43. Hosoglu S, Gundes S, Kolayli F, Karadenizli A, Demirdag K, Gunaydin $\mathrm{M}$, et al. Extended-spectrum beta-lactamases in ceftazidime-resistant Escherichia coli and Klebsiella pneumoniae isolates in Turkish hospitals. Indian J Med Microbiol. 2007;25(4):346-50.

44. Messai Y, Iabadene H, Benhassine T, Alouache S, Tazir M, Gautier $\mathrm{V}$, et al. Prevalence and characterization of extended-spectrum $\beta$-lactamases in Klebsiella pneumoniae in Algiers hospitals (Algeria). Pathol Biol. 2008;56(5):319-25.

45. Xiong Z, Zhu D, Zhang Y, Wang F. Extended-spectrum betalactamase in Klebsiella pneumoniae and Escherichia coli isolates. Zhonghua Yi Xue Za Zhi. 2002;82(21):1476-9.

46. Bora A, Hazarika NK, Shukla SK, Prasad KN, Sarma JB, Ahmed G. Prevalence of blaTEM, blaSHV and blaCTX-M genes in clinical isolates of Escherichia coli and Klebsiella pneumoniae from Northeast India. Indian J Pathol Microbiol. 2014;57(2):249-54.

47. Monstein HJ, Östholm-Balkhed A, Nilsson MV, Nilsson M, Dornbusch K, Nilsson LE. Multiplex PCR amplification assay for the detection of blaSHV, blaTEM and blaCTX-M genes in Enterobacteriaceae. APMIS. 2007;115(12):1400-8.

48. Hassan H, Abdalhamid B. Molecular characterization of extendedspectrum beta-lactamase producing Enterobacteriaceae in a Saudi Arabian tertiary hospital. J Infect Dev Ctries. 2014;8(3):282-8.

49. Ahmed OB, Asghar AH, Bahwerth FS. Prevalence of ESBL genes of Pseudomonas aeruginosa strains isolated from Makkah Hospitals, Saudi Arabia. Euro J Biol Med Sci Res. 2015;3(6):12-18.

50. Borges-Cabral A, Melo RCS, Maciel MAV, Lopes AC. Multidrug resistance genes, including blaKPC and blaCTX-M-2, among Klebsiella pneumoniae isolated in Recife, Brazil. Rev Soc Bras Med Trop. 2012;45(5):572-8.

51. Bina M, Pournajaf A, Mirkalantari S, Talebi M, Irajian G. Detection of the Klebsiella pneumoniae carbapenemase (KPC) in $K$. pneumoniae Isolated from the Clinical Samples by the Phenotypic and Genotypic Methods. Iran J Pathol. 2015;10(3):199-205.

52. Limbago BM, Rasheed JK, Anderson KF, Zhu W, Kitchel B, Watz N, Munro S, Gans H, Banaei N, Kallen AJ. IMP-producing carbapenem-resistant Klebsiella pneumoniae in the United States. Journal of clinical microbiology. 2011;49(12):4239-45.

53. Udomsantisuk N, Nunthapisud P, Tirawatanapong T, Dansuputra M. Molecular characterization of extended spectrum beta-lactamase among clinical isolates Escherichia coli and Klebsiella pneumoniae. J Med Assoc Thai. 2011;94(12):1504-12.

54. Iraz M, Özad Düzgün A, Sandallı C, Doymaz MZ, Akkoyunlu Y, Saral A, et al. Distribution of $\beta$-lactamase genes among carbapenemresistant Klebsiella pneumoniae strains isolated from patients in Turkey. Ann Lab Med. 2015;35(6):595-601.

55. Charrouf FO, Hamze M, Mallat H, Achkar M, Dabboussia F. Characterization of resistance genes in 68 ESBL-producing Klebsiella pneumonia in Lebanon. Med Mal Infect. 2014;44 (11-12):535-8.

56. Psichogiou M, Tassios PT, Avlamis A, Stefanou I, Kosmidis C, Platsouka E, et al. Ongoing epidemic of blaVIM-1-positive Klebsiella pneumoniae in Athens, Greece: a prospective survey. J Antimicrob Chemother. 2008;61(1):59-63.

57. Sonnevend A, Al Dhaheri K, Mag T, Herpay M, Kolodziejek J, Nowotny N, et al. CTX-M-15-producing multidrug-resistant enteroaggregative Escherichia coli in the United Arab Emirates. Clin Microbiol Infect. 2006;12(6):582-5. 
58. Ensor V, Jamal W, Rotimi V, Evans J, Hawkey P. Predominance of CTX-M-15 extended spectrum $\beta$-lactamases in diverse Escherichia coli and Klebsiella pneumoniae from hospital and community patients in Kuwait. Int J Antimicrob Agents. 2009;33(5):487-9.

59. Al-Agamy MHM, Ashour MSE-D, Wiegand I. First description of CTX-M $\beta$-lactamase-producing clinical Escherichia coli isolates from Egypt. Int J Antimicrob Agents. 2006;27(6):545-8.

60. Lima AMS, de Melo MES, Alves LC, Brayner FA, Lopes ACS. Investigation of class 1 integrons in Klebsiella pneumoniae clinical and microbiota isolates belonging to different phylogenetic groups in Recife, State of Pernambuco. Rev Soc Bras Med Trop. 2014;47(2):165-9.

61. Arakawa Y, Murakami M, Suzuki K, Ito H, Wacharotayankun R, Ohsuka S, et al. A novel integron-like element carrying the metallo- beta-lactamase gene blaIMP. Antimicrob Agents Chemother. 1995;39(7):1612-5.

62. Collis CM, Kim M-J, Partridge SR, Stokes H, Hall RM. Characterization of the class 3 integron and the site-specific recombination system it determines. J Bacteriol. 2002;184 (11):3017-26.

63. Correia M, Boavida F, Grosso F, Salgado MJ, Lito LM, Cristino $\mathrm{JM}$, et al. Molecular characterization of a new class 3 integron in Klebsiella pneumoniae. Antimicrob Agents Chemother 2003;47(9):2838-43.

64. Mobarak-Qamsari M, Ashayeri-Panah M, Eftekhar F, Feizabadi MM. Integron mediated multidrug resistance in extended spectrum beta-lactamase producing clinical isolates of Klebsiella pneumoniae. Braz J Microbiol. 2013;44(3):849-54. 